\title{
Напитки на основе продуктов переработки сахарного тростника
}

\author{
Карпенко Дмитрий Валерьевич \\ ФГБОУ ВО «Московский государственный университет пищевых производств» \\ Адрес: 125080, г. Москва, Волоколамское шоссе, д. 11 \\ E-mail:karpenkodv@mgupp.ru \\ Дышекова Милана Мухамедовна \\ ФГБОУ ВО «Московский государственный университет пищевых производств» \\ Адрес: 125080, г. Москва, Волоколамское шоссе, д. 11 \\ E-mail:dyshekovamm@mgupp.ru
}

\begin{abstract}
Одним из последствий глобализации как основной тенденции последних десятилетий является возрастание интереса потребителей определенного региона или страны к продуктам, в частности, напиткам, которые ранее локально не пользовались широкой популярностью. В статье приведена информация о напитках безалкогольных и алкогольных различной крепости, полученных из продуктов переработки сахарного тростника, представлен типичный химический состав данного виды сырья. Основное внимание уделено классификации кашасы и рома, технологическим стадиям процессов их производства, параметрам проведения этих стадий и их влиянию на потребительские характеристики этих напитков. Дана краткая история кашасы и рома, приведены сведения об их доле в сегменте крепких алкогольных напитков на мировом рынке. Отмечается, что принципы технологий кашасы и рома аналогичны, но может различаться последовательность проведения стадий производственного процесса. Подчеркнута роль вторичных дрожжевых метаболитов, накапливающихся при сбраживании сусла, в формировании качества готовых напитков, приведены основные группы этих соединений и их представители, их влияние на органолептические характеристики напитков брожения. Приведена информация о родах и видах микроорганизмов, развивающихся в процессе ферментации сусла при производстве кашасы и рома. Указана возможность использования различного оборудования для дистилляции сброженного сусла и организации этого процесса. В заключении отмечено, что в Российской Федерации целесообразно совершенствование технологии, в первую очередь, рома, например, за счет переработки нетрадиционного сахарсодержащего сырья.
\end{abstract}

Ключевые слова: сахарный тростник, напитки из сахарного тростника, кашаса, ром, технологии производства

\section{Введение}

У многих россиян сахарный тростник ассоциируется только с Кубой, сахаром и ромом. А ром - с пиратами. Если это мнение справедливо, то лишь отчасти.

Действительно, культивирование сахарного тростника в Карибском регионе имеет давнюю историю. Сообщается, что в 1493 году Христофор Колумб привез сахарный тростник с Канарских островов во время второго плавания в Вест-Индию. ${ }^{1}$ Посадки этой культуры на Эспаньола (Гаити) были очень успешными, и уже в 1516 году начались поставки сахара с этого острова в Испанию.
Конечно, это растение является одним из самых значимых видов сырья для производства сахара в ряде стран мира. На Индию и Бразилию сегодня приходится выпуск 50\% всего тростникового сахара; Китай, Таиланд и Пакистан располагаются на 3, 4 и 5 местах по производству такого сахара. ${ }^{2}$

Несомненно, ром, как алкогольный напиток, входил в ежедневный рацион моряков флотов многих стран, не только флибустьеров (Копелев, 2011). Пожалуй, более прочих, включением рома в ежедневный судовой паек славился Британский флот (Davies, 2018) - каждый моряк ежедневно получал около 300 мл неразбавленного рома. ${ }^{3}$

\footnotetext{
${ }_{1}$ Distilled Sunshine. Classification of rum. https://distilledsunshine.wordpress.com/2017/07/05/classification-of-rum/ (дата обращения: 25.11.2020).

2 Там же

3 Там же
} 
Но этим далеко не исчерпываются регионы выращивания, способы использования сахарного тростника, а, значит, и спектр продуктов его переработки, в том числе, и напитков различной крепости. Целью данной статьи является обзор существующей литературы для расширения информированности российских потребителей и специалистов о напитках различной крепости, производимых из продуктов переработки сахарного тростника.

\section{Материалы и методы исследования}

При работе с источниками использовались поисковые запросы в базе данных Scopus о безалкогольных и алкогольных напитках различной крепости, полученных из продуктов переработки сахарного тростника, в том числе кашасы и рома. Анализировались источники за последние 10 лет, на русском и иностранных языках, опубликованных в профильных журналах, а также монографии, посвященные тематике исследования. Были также проанализированы некоторые опубликованные ранее источники, если они представляли интерес по исследуемым вопросам.

\section{Результаты и их обсуждение}

Были проанализированы 41 источник литературы (в основном, обзорные статьи и монографии), в том числе 3 источника на русском языке и 38 источников на английском (36 источников) и португальском (2 источника) языках. Из них основная часть проанализированных статей $(87,8 \%)$ опубликовано за последние 10 лет, с 2010-2020 годы (36 источников), в том числе за последние 4 года с 2017-2020 (25 источников). Также были проанализированы $(12,2 \%)$ наиболее значимые работы, начиная с 1998 года (5 источников).

\section{Характеристика сахарного тростника как сы- рья пищевых производств}

Сахарный тростник (Saccharum spp.) - это многолетняя трава с цилиндрическим стеблем, который достигает около 3 м в высоту. Считается, что начало его культивированию было положено в Папуа Новой Гвинее около 10000 лет назад. Химический состав (Таблица 1) включает 75\% воды и 25\% органических веществ. Стебель содержит сахарозу, извлекаемый из него сок и используется производства тростникового сахара из тростника.
Таблица 1

Химический состав стеблей сахарного тростниka (Medeiros, Matos, Monteiro, De Carvalho, \& Soccol, 2017)

\begin{tabular}{lc}
\hline \multicolumn{1}{c}{ Компонент } & $\begin{array}{c}\text { Концентра- } \\
\text { ция (г/100 г) }\end{array}$ \\
\hline Вода & $65-75$ \\
Сахара & $12-18$ \\
Сахароза & $11-18$ \\
Глюкоза & $0.2-1,0$ \\
Фруктоза & $0-0,6$ \\
Пищевые волокна & $7.0-17.0$ \\
Целлюлоза & $5.0-6.5$ \\
Гемицеллюлозы & $1.8-2.3$ \\
Лигнин & $1.5-2.5$ \\
Азотистые соединения & $0.3-0.6$ \\
Липиды (воски и жиры) & $0.15-0.25$ \\
Органические кислоты & $0.1-0.15$ \\
Пектиновые вещества и камеди & $1.5-0.25$ \\
Золы & $0.3-0.8$ \\
\hline
\end{tabular}

Лучшими для выращивания сахарного тростника являются жаркие, влажные субтропические и тропические зоны (средние температуры 60-90 градусов по Фаренгейту, что соответствует 16$\left.32^{\circ} \mathrm{C}\right)$; песчаные почвы, не подходящие для деревьев; низкие высоты над уровнем моря; ровная или с малым перепадом высот местность. Сахарный тростник может выдерживать наводнения; рост продолжается даже ночью. Плантация может использоваться в течение четырех лет, после чего необходима новая культура; каждое растение при правильном уходе может дать 7-10 урожаев. ${ }^{4}$ Отмечается (Oswaldo et al., 2019) что это растение чувствительно к влажности почвы, а ее недостаток существенно снижает продуктивность культуры.

\section{Безалкогольные и слабоалкогольные напитки из сока сахарного тростника}

Помимо использования в качестве сырья для производства сахара после осветления (Meng et al., 2020) или традиционных для Азиатских стран сахаристых продуктов, получаемых без осветления/центрифугирования и считающихся более полезными (Kumar \& Singh, 2020), сок сахарного тростника во многих азиатских стра-

\footnotetext{
${ }_{4}$ The rum authority. Manual. www.therumauthority.com.
} 
нах, включая такие густонаселенные, как Индия и Китай, употребляют непосредственно как напиток, утоляющий жажду и обладающий, благодаря своему химическому составу, богатому минералами и органическими кислотами, полезными для здоровья свойствами (Arif, Batool, Nazir, Khan, \& Khalid, 2019; Chinnadurai, 2017; Sneh, Anurag, Kuna, \& Dhanlakshmi, 2012; Xiao, Liao, \& Guo, 2017). Этот сок пьют в чистом виде или смешивают с соком лайма, имбирным соком и кокосовой водой (Pradhan, Kumar, Singh, \& Pisalkar, 2020). Традиционно сок сахарного тростника получали кустарным способом непосредственно перед употреблением. В настоящее время разрабатываются способы промышленного производства такого сока как напитка с повышенной стабильностью, включающие современные технологические приемы, например, микроволновую обработку (Pradhan et al., 2020). Отмечается (Dal Magro, Bulegon, \& Gomes, 2019), что благодаря своим питательным свойствам сок сахарного тростника имеет потенциал для удовлетворения энергетических потребностей спортсменов. Исследуется возможность получения порошка из сока сахарного тростника с помощью сублимационной сушки с целью приготовления на его основе спортивных напитков. Предложено также использовать распылительную сушку для порошков на основе сока сахарного тростника (Nishad, Selvan, Mir, \& Bosco, 2017).

Группа бразильских исследователей опубликовала результаты работы, посвященной разработке технологии алкогольного напитка из средней крепости (8\% об.), отнесенного ими к вину (Resende Oliveira et al., 2018). Технология аналогичного напитка крепостью около 10\% об. несколькими годами ранее была разработана и коллективом мексиканских специалистов (Rivera-Espinoza, Valdez-López, \& Hernandez, 2005). В «серой» литературе встречаются также упоминания о «слегка» ферментированном, вследствие этого, очевидно, слабоалкогольном напитке “Basi”, производимом Филиппинах и в Гайане.

Кашаса и ром: история, определения, классификации, место на рынке алкогольной продукции

Известными и популярными во многих регионах мира являются крепкие алкогольные напитки, которые производят либо из сока сахарного тростника (кашаса), либо из тростниковой мелассы (ром).
Кашаса - типичное и эксклюзивное наименование спиртного напитка, произведенного в Бразилии, имеющего крепость от 38 до 48\% об., полученного перегонкой сброженного сока сахарного тростника (Medeiros et al., 2017). Название “cachaçа”, возможно, произошло от термина “cagaçа”, использовавшийся для обозначения осадка, остающегося при переработке сока сахарного тростника в производстве сахара. В период колониальной зависимости Бразилии параллельно с производством сахара возросло и производство напитков из сахарного тростника, возросли их экономическая и социальная роли. Кашаса рассматривалась как угроза интересам Португалии, потому что португальскую “bagaceira” (дистиллят, полученный из виноградной мезги, выдержанный в дубовых бочках и разбавленный до крепости $40^{\circ}$ ) начали употреблять в меньших количествах. Кашаса стала фактором и символом сопротивления бразильского народа против Португальского господства, завершившегося независимостью Бразилии (Alcarde, 2014).

Бразильские «тростниковые» спирты высоко ценятся за их характерные вкус и аромат, которые могут быть дополнительно улучшены за счет выдержки в деревянных бочках. Кроме влияния на органолептические характеристики напитка (Castro, Bortoletto, Silvello, \& Alcarde, 2020; Maia, Marinho, \& Nelson, 2020; Vivas, Gaulejac, Bourden-Nonier, Mouche, \& Rossy, 2020), контакт с древесиной повышает содержание в нем антиоксидантов (Bukovsky-Reyes, Lowe, Brandon, \& Owens, 2018). Министерство сельского хозяйства Бразилии разработало нормативный документ, в котором повторены определения кашасы и спиртов из сахарного тростника, а также установлены новые градации для выдержанных продуктов (Medeiros et al., 2017). Законодательно установленная разница между кашасой и «тростниковым» спиртом заключается, прежде всего, в том, из какого сусла получен напиток. Кашаса должна производиться исключительно путем сбраживания сусла, приготовленного из сока сахарного тростника.

Нормативные документы устанавливают также стандарты идентичности и качества спиртов из сахарного тростника и кашасы, особо выделяя следующие показатели: содержание алкоголя и общего сахара, летучих кислот в пересчете на уксусную кислоту, высших спиртов (выраженное как сумма н-пропилового спирта, изобутилового спирта и изоамилового спирта), фурфурола, гидроксиметилфурфурола, альдегидов и общих эфиров в пересчете на этилацетат (Таблица 2). 
Таблица 2

Максимально допустимые концентрации компонентов и «загрязнителей» в «тростниковых» спиртах и кашасе в соответствии с бразильским законодательством (Medeiros et al., 2017)

\begin{tabular}{|c|c|}
\hline $\begin{array}{c}\text { Соединение/группа } \\
\text { веществ }\end{array}$ & $\begin{array}{c}\text { Максимально допусти- } \\
\text { мая концентрация (мг/100 } \\
\text { см³ }^{3} \text { безводного спирта) }\end{array}$ \\
\hline Летучая кислотность & 150 \\
\hline $\begin{array}{l}\text { Сложные эфиры в пе- } \\
\text { ресчете на этилацетат }\end{array}$ & 200 \\
\hline $\begin{array}{l}\text { Альдегиды в пересче- } \\
\text { те на ацетальдегид }\end{array}$ & 30 \\
\hline $\begin{array}{l}\text { Фурфурол и гидрок- } \\
\text { симетилфурфурол }\end{array}$ & 5 \\
\hline $\begin{array}{l}\text { Всего высших спир- } \\
\text { тов: изоамил, изобу- } \\
\text { тил и 1-пропанол }\end{array}$ & 360 \\
\hline Коэффициент конгенеров & $200-650$ \\
\hline Метанол & 25 \\
\hline Медь ${ }^{\mathrm{b}}$ & 0.5 \\
\hline Этилкарбамат ${ }^{\mathrm{b}}$ & 0,015 \\
\hline Акролеин & 5 \\
\hline 2-бутанол & 10 \\
\hline н-Бутиловый спирт & 3 \\
\hline
\end{tabular}

Примечание: авероятно, под конгенерами авторы цитируемого источника имеют в виду вещества, отличные от этилового спирта (желательные или нежелательные), также образующихся во время ферментации. ${ }^{\mathrm{b}}$ выражено в мг $/ 100$ см$^{3}$ напитка.

Стандарты также требуют контроля содержания «загрязнителей», таких как этилкарбамат, акролеин, 2-бутанол, н-бутиловый спирт, свинец, мышьяк, медь и метанол (Medeiros et al., 2017). Установленные стандартами ограничения по отношению к ксенобиотикам нацелены на обеспечение безопасности напитка; это не значит, что «тростниковые» спирты (равно как и кашасу), соответствующие требованиям этих документов, следует рассматривать как продукты с более высокими сенсорными характеристиками. Бразильское законодательство разрешает добавление сахара в кашасу до 6 г/дм ${ }^{3}$ сахарозы. При превышении этого уровня продукт должен маркироваться как «подслащенный» напиток.

По нашему мнению, необходимо обратить внимание на упоминаемые в Таблице 2 конгенеры, иначе говоря, вторичные дрожжевые метаболиты, образующиеся при сбраживании сусла и играющие существенную роль в формировании органолептических характеристик напитков брожения разной крепости. Основные группы конгенеров, их представители и оттенки вкуса, аромата, придаваемые этими веществами, приведены в Таблице 3 (Walker \& Stewart, 2016).

В настоящее время в Бразилии производится около 1,7 млрд. литров кашасы, из которых примерно $75 \%$ производится промышленным и $25 \%$ кустарным способом (Capobiango, Oliveira, \& Cardeal, 2013). Различие между напитком, производимым промышленным способом, и кустарной кашасой, заключается, в основном, в способе дистилляции. В индустриальном масштабе проводят непрерывную дистилляцию в колонне из нержавеющей стали. В кустарном производстве используют медные перегонные кубы. Кроме, а отчасти и вследствие этого кустарная кашаса отличается от промышленно произведенной по органолептическим и химическим характеристикам. Ремесленные сорта кашасы производится на небольших заводах, которые обычно являются семейными предприятиями (Medeiros et al., 2017).

Сегодня кашаса - четвертый в мире по объему производства (и потребления) алкогольный напиток в категории локальных спиртных напитков, уступая только байцзю, водке и соджу (Alcarde, 2014). Существует более 40000 производителей кашасы и около 4000 торговых марок. Штатами Бразилии с самым высоким производством кашасы являются Сан Пауло (44\%), Пернамбуку (12\%), Сеара (12\%), Минас-Жерайс (8\%) и Параиба (8\%). По некоторым оценкам, в Бразилии около $70 \%$ кашасы употребляется в чистом виде, остальное - в виде коктейлей (Medeiros et al., 2017).

Ром - это дистиллированный спирт, изготовленный из продуктов переработки сахарного тростника. Колонизация Гаити испанцами, а других островов архипелага французами, голландцами и англичанами и развитие на них производства сахара сделала этот напиток одним из символов Карибского моря (Wells, Goudge, Tricarico, Murphy, \& Fox, 2019). При этом первое упоминание о производстве рома принадлежит португальцам, которые занимались переработкой сахарного тростника в регионах Пернамбуку и Баия в Бразилии (Harris \& West, 1988). Первоначально ром имел низкое качество и не пользовался таким престижем, как сегодня. Многие рабовладельцы предлагали этот напиток своим рабам с целью их «успокоения» и более легкого обращения с ними. Ром потребляли также самые бедные слои населения.

Однако в настоящее время благодаря совершенствованию технологии ром обладает харак- 
Таблица 3

Вторичные дрожжевые метаболиты как конгенеры в напитках (Walker \& Stewart, 2016)

\begin{tabular}{|c|c|c|}
\hline $\begin{array}{c}\text { Класс мета- } \\
\text { болитов }\end{array}$ & Примеры соединений & Комментарии \\
\hline Высшие спирты & $\begin{array}{l}\text { Изоамиловый спирт, фе- } \\
\text { нилэтанол, изопропанол }\end{array}$ & $\begin{array}{l}\text { В определенных диапазонах концентраций высшие спир- } \\
\text { ты (сивушные масла) придают желаемый вкус и аромат сбро- } \\
\text { женным напиткам, особенно дистиллированным спиртам }\end{array}$ \\
\hline Сложные эфиры & Этилацетат & $\begin{array}{l}\text { Придают фруктовый и цветочный вкус и аромат фер- } \\
\text { ментированным напиткам, особенно пиву и вину. }\end{array}$ \\
\hline $\begin{array}{l}\text { Карбонильные } \\
\text { соединения }\end{array}$ & Ацетальдегид & $\begin{array}{l}\text { При превышении вкусового порога может придавать пиву } \\
\text { привкус «травяной» или «зеленого яблока», но его мож- } \\
\text { но удалить на стадии дображивания и созревания }\end{array}$ \\
\hline $\begin{array}{l}\text { Органиче- } \\
\text { ские кислоты }\end{array}$ & $\begin{array}{l}\text { Янтарная кислота, лимонная } \\
\text { кислота, уксусная кислота }\end{array}$ & $\begin{array}{l}\text { Эти соединения придают терпкость или «остроту» сброженным } \\
\text { напиткам. Наличие некоторых кислот, в первую очередь, мо- } \\
\text { лочной, указывают на нежелательную бактериальную порчу }\end{array}$ \\
\hline Полиолы & Глицерин & $\begin{array}{l}\text { Синтезируется при нормальном метаболизме дрож- } \\
\text { жей, или когда клетки дрожжей испытывают осмотиче- } \\
\text { ский стресс; придает вязкость, положительно сказывающуюся } \\
\text { на восприятии сброженных напитков, особенно вин }\end{array}$ \\
\hline $\begin{array}{l}\text { Вициналь- } \\
\text { ные дикетоны }\end{array}$ & Диацетил, пентан-2,3-дион & $\begin{array}{l}\text { Диацетил в большинстве сортов пива нежелателен из-за } \\
\text { придания напитку привкуса прогорклого масла или ири- } \\
\text { ски, но при дображивании пива его концентрация мо- } \\
\text { жет быть снижена до значений ниже вкусового порога }\end{array}$ \\
\hline Соединения серы & $\begin{array}{l}\text { Сероводород, диметилсуль- } \\
\text { фид, диоксид серы, тиолы }\end{array}$ & $\begin{array}{l}\text { Активно участвуют в формировании вкуса и аромата напит- } \\
\text { ков; например, в пиве диметилсульфид (ДМС), если он при- } \\
\text { сутствует в низких концентрациях - желательный атрибут } \\
\text { лагеров, но в более высоких придает неприятный привкус. }\end{array}$ \\
\hline $\begin{array}{l}\text { Фенольные со- } \\
\text { единения }\end{array}$ & 4-винилгваяколь & $\begin{array}{l}\text { Некоторые дрожжи, включая дикие, могут вызывать не- } \\
\text { желательные фенольные привкусы и ароматы. Однако, } \\
\text { гвоздичное соединение, 4-винилгваяколь, желательно в не- } \\
\text { которых сортах пива и может синтезироваться некоторы- } \\
\text { ми штаммами дрожжей S. cerevisiae верхового брожения }\end{array}$ \\
\hline
\end{tabular}

теристиками, которые придают ему большую историческую и гастрономическую ценность. В настоящее время производится во многих странах, включая Италию, Францию, Англию, Голландию. Перечень государств, в которых ром является достаточно широко употребляемым напитком, конечно, гораздо шире. Входит в их число и Россия (Чеботарева, 2015), причем на нашем «алкогольном» рынке ром был представлен уже в начале XIX века (Быстров, 2016). Обладая уникальным вкусом и ароматом, используется в коктейлях, которые насчитывают множество различных рецептов. По объему производства ром занимает четвертое место среди наиболее популярных крепких алкогольных напитков (Таблица 4).
Таблица 4

Объем продаж по категориям ${ }^{5}$

\begin{tabular}{lccc}
\hline \multicolumn{1}{c}{ Категория } & $\mathbf{2 0 1 8}$ & $\mathbf{2 0 1 9}$ & \%+/- \\
\hline $\begin{array}{l}\text { Крепкие спирт- } \\
\text { ные напитки }\end{array}$ & 2395878866.67 & 2386102455.56 & $-0.4 \%$ \\
Белые спирты & 399702300.00 & 407592088.88 & $2.0 \%$ \\
Виски & 389759577.78 & 405414877.78 & $4.0 \%$ \\
Бренди и коньяк & 168551600.00 & 169799177.77 & $0.7 \%$ \\
Ром & 149994288.89 & 150600088.89 & $0.4 \%$ \\
Ликеры & 117988122.22 & 119735600.00 & $1.5 \%$ \\
Текила и мескаль & 36778566.67 & 39220933.33 & $6.6 \%$ \\
\hline
\end{tabular}

5 The Spirits Business. Market overview. https://www.thespiritsbusiness.com/2020/06/market-overview-2/ (дата обращения: 22.12.2020). 
Ром определяется WIRPA (Вест-Индийская Ассоциация производителей рома и спиртных напитков) как любой спирт, изготовленный из сбраживаемого сахара из сахарного тростника с максимальным содержанием алкоголя 96\% об./об. Ром можно производить полностью из мелассы, сиропа из сахарного тростника или сока сахарного тростника. Обычной практикой для французской культуры (франкоговорящих стран Карибского региона) является использование только сока сахарного тростника; эта разновидность рома называется «агриколь» (“agricole”), но объем ее производства составляет всего $3 \%$ от мирового, тогда как рома из тростниковой мелассы - до 97\% (Harris \& West, 1988).

В соответствии с американским законодательством ром определяется как алкогольный дистиллят из сброженного сока сахарного тростника, сиропа сахарного тростника, тростниковой мелассы или других побочных продуктов сахарного тростника [sic] крепостью не менее 95\% об., произведенный таким образом, чтобы дистиллят обладал присущими рому вкусом, ароматом и характеристикам. Напиток, разливаемый в бутылки, должен иметь крепость не менее $40 \%$ об.. Ромом может также называться смесь, состоящая только из таких дистиллятов. Следует отметить, что, в отличие от правил США для виски, правила для рома не содержат требований к тому, чтобы он выдерживался в дубовых бочках в течение определенного периода времени. В правилах США также не указывается какой-либо географический регион, в котором может производиться ром (Murtagh, 2003).

Другой источник сообщает, что крепость рома, разлитого в бутылки, должна быть не менее $35,4 \%$ об.; в него при купажировании могут быть добавлены специи и жженый сахар для формирования желаемых органолептических характеристик. Допустимо использование активированного угля для корректировки цветности. При этом содержание «добавленных» сахаров не должно превышать 6 г/дм ${ }^{3} ;$ концентрация конгенеров не должна быть менее 40 и более $500 \mathrm{мг} /$ дм $^{3}$ безводного этилового спирта. Готовый напиток, содержащий более низкие концентрации этилового спирта, должен называться “aguardiente” (Harris \& West, 1988).

Британские нормативные документы определяют ром как спирт, полученный непосредственно из продуктов переработки сахарного тростника в странах, выращивающих сахарный тростник.
В соответствии с действующим в Российской Федерации ГОСТ, «ром - спиртной напиток, изготавливаемый из ромовых дистиллятов, получаемых путем дистилляции сброженного сусла из мелассы, образующейся при производстве тростникового сахара, или дистилляции сока сахарного тростника, или разбавления ромового дистиллята исправленной водой» ${ }^{6}$. При этом дистиллят могут как выдерживать, так и не выдерживать в контакте с древесиной.

Здесь представляется любопытным отметить предположение, что, выражаясь современным языком, выдержку ромовых дистиллятов начали практиковать с 1600-х годов, когда морские перевозчики рома обнаружили, что длительная транспортировка в деревянных бочках значительно улучшает качество напитка, а его цвет становится тем более интенсивным, чем длительнее было такое «путешествие». Со временем сложилась традиция выдерживать ромовые дистилляты в дубовых бочках из-под Бурбона (кукурузного виски) (Bamforth et al., 2019). Сегодня используется технологический прием, в соответствии с которым для улучшения органолептических характеристик готового напитка дистиллят выдерживают в емкости, куда также помещают щепки. Более того, опубликована работа (Vivas et al., 2020), авторы которой предлагают добавление с той же целью сухого экстракта сердцевины дуба.

Определенная расплывчатость приведенных выше определений обуславливает широкое разнообразие типов рома, начиная от светлых, органолептически почти нейтральных, не содержащих $\mathrm{CO}_{2}$, до сильно ароматизированных темных, также не содержащих углекислого газа напитков. Различия между типами и сортами рома определяются как перерабатываемым сырьем, так и особенностями методов производства напитка (Belmonte-Sánchez et al., 2018; Belmonte-Sánchez, Romero-González, Arrebola, Vidal, \& Frenich, 2019; Coelho et al., 2020; Murtagh, 2003).

Ром, сделанный из сока сахарного тростника, имеет землистый, травянистый, а иногда и минеральный оттенки аромата, тогда как сорта, полученные из тростниковой мелассы, могут иметь цветочные и пряные ноты, сбалансированные с легкой сладостью (Murtagh, 2003).

По поводу классификации видов рома не существует единой точки зрения, в разных странах

\footnotetext{
${ }^{6}$ ГОСТ 33458-2015-2015. (2015). Ром. Технические условия. М.: Стандартинформ.
} 
и регионах мира она базируется на различных принципах и подходах: технология производства, цвет готового напитка, крепость, место/страна/регион происхождения.

Нам представлялось целесообразным привести три из возможных. Первая основывается на видах рома в торговой сети, прежде всего, Северной Америки и, очевидно, учитывает предпочтения потребителей ${ }^{7}$.

Светлый ром - в большинстве случаев является мягким, легким по вкусу, не выдержанным. Чистота вкуса обусловлена, как правило, фильтрацией. Может производиться из тростникового сока.

Золотой ром - обычно имеет более богатый вкус, дистиллят выдерживается в дубовых бочках в течение более длительного периода времени. Может производиться из сока сахарного тростника.

Темный ром - из дистиллятов, выдержанных в течение длительного времени. Тем не менее, их цвет и аромат почти всегда обусловлен теми или иными добавками.

Черный ром - как правило, из самых выдержанных дистиллятов, имеет самый насыщенный вкус. Как правило, произведен из тростниковой мелассы, а не из сока. При этом их цвет и аромат в значительной степени зависят от добавок.

Пряный ром - любой ром с добавлением специй и иногда жженого сахара. Большинство сортов этого типа имеют более темный цвет и «основаны» на золотом роме. Некоторые из них значительно темнее, однако многие более дешевые бренды изготавливаются из недорогого белого рома, а насыщенный цвет достигается за счет добавления жженого сахара. Могут добавлять такие специи, как корица, розмарин, анис, перец, гвоздика и кардамон.

Кроме того, могут быть выделены следующие категории:

Военно-морской ром - технически бессмысленная категория, подразумевает любой сорт рома, когда-то популярный в британском флоте. Но британские военные моряки употребляли много разных сортов рома, поэтому сорта данной группы никогда не имели единого стиля.
Ароматизированный ром - имеет аромат фруктов, таких как банан, манго, апельсин, ананас, кокос, карамболь или лайм. Как правило, его крепость менее 40\% об. В основном сорта этой категории используют для придания аромата тропическим напиткам, но также часто пьют в чистом виде или со льдом. Экстракты плодового сырья добавляют после сбраживания сусла и дистилляции бражки. Однако, в дистиллят могут добавляться и ароматизаторы, идентичные натуральным.

Крепкий ром имеет гораздо большее, чем стандартное (40\% об.) содержание этанола - от 75 до $80 \%$ об. Обычно его используют для приготовления коктейлей.

Ром премиум-класса - как некоторые другие крепкие напитки, такие как коньяк и шотландский виски, относятся к особой рыночной категории. Обычно это «бутик-бренды», которые представляют собой тщательно произведенный и выдержанный ром. У них больше характера и вкуса, чем у их «смешанных» аналогов, обычно их употребляют в чистом виде.

Классификация Гаргано (Gargano) предпринимает попытку учесть особенности технологии напитка. В соответствии с ней выделяются четыре следующие категории.

1. Чистый одинарный ром - произведен из мелассы и, во всех случаях, периодической дистилляцией в перегонных кубах, на одном заводе. К этой же категории относится agricole, если соблюдены указанные выше условия перегонки и происхождения дистиллятов.

2. Купажированный одинарный ром - получают, смешивая дистилляты, полученные в перегонных кубах и в колоннах непрерывного действия, произведенные на одном предприятии.

3. Традиционный ром - произведен из дистиллятов, полученных в кустарных колоннах на основе тростниковой мелассы или сока.

4. (Современный) ром - из дистиллятов на основе мелассы получают в современных заводских колоннах непрерывного действия, обычно имеющих крепость более 95\% об. Ром такой категории легче, менее богат сложными эфирами, имеет почти нейтральный аромат. В него зачастую добавляют сахар, красители, специи или ароматизаторы.

${ }^{7}$ Distilled Sunshine. Classification of rum. https://distilledsunshine.wordpress.com/2017/07/05/classification-of-rum/ (дата обращения: 25.11.2020). 
И, наконец, в соответствии с третьей классификацией, основанной на типе ферментации сусла, выделяют:

- «легкий» ром - из сусла, при сбраживании которого накапливается мало конгенеров и много этанола. Как правило, использование штаммов дрожжей рода Saccharomyces обеспечивает более высокий выход этанола (Medeiros et al., 2017).

- «тяжелый» ром - получают из сусел с высоким содержанием сахаров, бражка имеет более высокую концентрацию конгенеров и низкое содержание этанола из-за условий сбраживания. В большинстве случаев сбраживание сусла ведут штаммами дрожжей рода Schizosaccharomyces, иногда проводят спонтанную ферментацию или процесс с участием бактериальных инокулятов. Симбиотическое развитие бактерий и дрожжей приводит к накоплению большого количества конгенеров, формирующих «характер» рома (Medeiros et al., 2017).

На многих островах, бывших колониями Великобритании, к бродящему суслу добавляют жидкость под названием “dunder”. Она представляет собой побочный продукт дистилляции; это фракция, которая остается в перегонном кубе и содержит сахара, мертвые дрожжевые клетки и растворенные сухие вещества. Эту жидкость ферментируют пу- тем инокуляции диких бактерий, прежде чем добавить к бродящему суслу. Ферментированный “dunder” увеличивает накопление конгенеров и скорость сбраживания «основного» сусла за счет действия бактерий (Medeiros et al., 2017; Harris \& West, 1988).

\section{Технологические аспекты производства кашасы и рома}

Помимо вида сырья, на качественные характеристики крепких «тростниковых» напитков существенно влияют особенности технологии, которые также представлялось целесообразным рассмотреть в данной статье. Принципиальные схемы производства рома и кашасы представлены на Рисунке 1.

В целом, сравнивая два представленных технологических процесса, можно, с нашей точки зрения, заключить, что они сопоставимы по перерабатываемому сырью, сложности, «набору» технологических стадий, хотя порядок проведения некоторых из них может отличаться. При этом различия параметров, при которых ведут процессы производства этих алкогольных напитков, приводят к существенной разнице их органолептических характеристик, позволяет получать широкий спектр сортов каждого из них, заметно отличающихся по своим потребительским характеристикам.
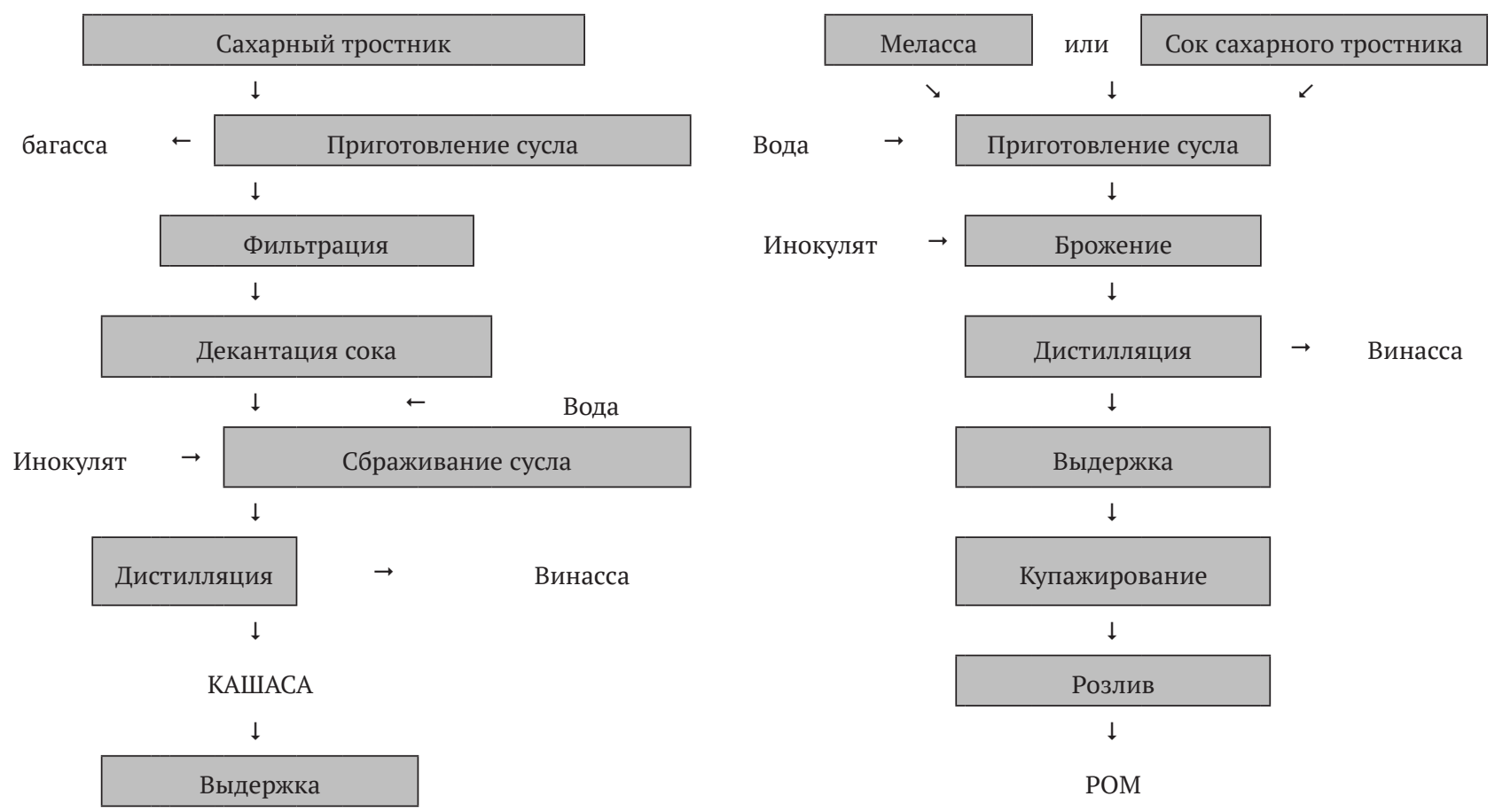

Рисунок 1. Принципиальные схемы производства кашасы и рома (Medeiros et al., 2017) 
Технология кашасы включает стадии, краткое описание которых приведено ниже.

Собранный тростник рекомендуется выгружать и мыть на столе, подвешенном на тросах или цепях для облегчения разгрузки. Это важно для предотвращения инфицирования сырья, в противном случае происходящего при контакте с землей. Между приемкой сырья и его измельчением должно пройти не более 24 ч с целью избежать снижения качества тростника из-за порчи и образования высших спиртов.

Для получения высокосахаристого сока и отделения твердой фракции стебли сахарного тростника измельчают в цилиндрических мельницах (Do Nascimento de Silva, Verruma-Bernardi, \& de Oliveira, 2020). Эффективность помола определяется количеством экстрагированной сахарозы на количество обработанного сахарного тростника за единицу времени. Значительная часть сахаров, накопленных при культивировании сахарного тростника на плантации, теряется на различных стадиях производственного цикла. Низкая эффективность устройств для извлечения сока приводит к высоким потерям сахаров. Условия экстракции следует улучшать, так как объем произведенного напитка напрямую зависит от количества извлеченного сока сахарного тростника.

Важно, чтобы свежевыжатый сок сахарного тростника был пропущен через сито с мелкими ячейками. Сито должно быть выполнено из нержавеющей стали, так как этот материал инертен к компонентам химического состава тростникового сока, а конструкция сита должна способствовать очистке сока и минимизировать риски его инфицирования. После фильтрации сок направляют в отстойник, в котором от него отделяются примеси (частицы почвы и мелкие фрагменты стеблей сахарного тростника). В резервуаре-отстойнике концентрацию экстрактивных веществ доводят до 14-16\% ( ${ }^{\circ}$ Brix). Сок с концентрацией сухих веществ более $16 \%$ необходимо разбавить для обеспечения плавного протекания процесса ферментации [sic]. Сбраживание неразбавленного сока будет неполным, медленным, в его ходе будут образовываться и сохраняться в готовом напитке нежелательные соединения (Medeiros et al., 2017).

Сбраживание сусла - критически важная стадия в процессе производства кашасы. На ней образуются ароматические соединения, формирующие органолептические характеристики, присущие напитку. В начале стадии в присутствии кислорода происходит размножение популяции дрожже- вых клеток. Затем интенсифицируется спиртовое брожение, в ходе которого накапливается этанол. Параллельно синтезируются побочные продукты (Medeiros et al., 2017), такие как углекислый газ [sic] и другие метаболиты (глицерин, альдегиды, сложные эфиры и органические кислоты), а также соединения, формирующие органеллы дрожжевых клеток и обеспечивающие их адаптацию и выживание в условиях среды культивирования (сбраживаемого сусла). Среди этих, более чем 250 химических соединений, образуются и конгенеры, участвующие в формировании «букета» кашасы. Именно наличие этих соединений в сбалансированных пропорциях и отличает кашасу от водно-спиртового раствора.

На большинстве предприятий по производству кашасы используются периодические или полупериодические (доливные) способы ферментации, последние позволяют дрожжевым клеткам избежать осмотического стресса.

Сбраживание сусла (ферментация) начинается с внесения посевного материала (инокулята) в субстрат. Эта стадия проводится в условиях, оптимальных для развития дрожжевой популяции. При сбраживании периодическим способом в среду не добавляют ничего, кроме кислорода, необходимого в начале этой технологической стадии для интенсивного накопления микробной биомассы. В случае необходимости в среду культивирования могут вносить также пеногаситель и кислотные или щелочные растворы для поддержания заданного значения $\mathrm{pH}$. Существует корреляция между кислотностью сбраживаемой среды и скоростью роста дрожжей. Считается, что дрожжи хорошо растут при $\mathrm{pH}$ из диапазона 5,0 - 6,0, а для синтеза этанола оптимальное значение $\mathrm{pH}$ составляет 4,5. Сок сахарного тростника имеет $\mathrm{pH}$, равное 5,5. Подкисление сусла необходимо проводить перед инокуляцией, это способствует ферментации и подавляет развитие бактериальных популяций. Оптимальными являются температуры среды культивирования от 28 до $32^{\circ} \mathrm{C}$. При реализации доливного способа культивирования питательные вещества (субстрат) добавляют небольшими порциями на протяжении всей ферментации. При крупномасштабном производстве кашасы могут вести непрерывный способ культивирования (сбраживания): в стерилизованную питательную среду (сусло), в которой уже идет процесс брожения непрерывно подается смесь сбраживаемых сахаров и других питательных веществ в определенном соотношении, а также суспензия микроорганизмов из биореактора. Таким образом повышается выход дрожжевых метаболитов и 
уменьшаются эксплуатационные проблемы [sic]. Брожение считают законченным, когда выделение углекислого газа значительно ослабевает, и клетки оседают на дно танка брожения. Продолжительность процесса составляет около 24 часов. Крупные предприятия могут подвергать сброженное сусло центрифугированию и повторно использовать собранные при этом дрожжи (Alcarde, 2014).

Кашасу могут производить с использованием нативных («диких») дрожжей, естественно присутствующих в окружающей среде. На небольших предприятиях посевной материал (инокулят) готовят из пасты, состоящей из рисовых отрубей, кукурузной муки, сухарей, сока лимонов или сока кислых апельсинов (Medeiros et al., 2017). Разбавленный сок сахарного тростника добавляют с 24-часовыми интервалами. Процесс повторяется до тех пор, пока объем инокулята не достигнет 20\% объема сбраживаемого сусла. Хотя это является обычной практикой, основная проблема заключаются в присутствии посторонних микроорганизмов и длительном периоде, необходимом для достижения требуемого объема инокулята. Использование селекционированных штаммов дрожжей позволяет избежать колебаний качества напитка и способствует более быстрому «запуску» процесса брожения. По сравнению со спонтанным брожением, это обеспечивает меньший риск заражения, более быструю и равномерную скорость брожения, меньшую конкуренцию за основные питательные вещества, более высокую эффективность брожения и более низкий уровень остаточных/несброженных сахаров (Campos et al., 2010). В общем, штаммы Saccharomyces cerevisiae выделяют и отбирают из сбраживаемых сред. Эти штаммы характеризуются высоким выходом спирта и устойчивостью к высоким концентрациям этанола. Кроме того, при выборе штамма дрожжей учитываются морфологические и физиологические характеристики, например, скорость и глубина сбраживания сока сахарного тростника; низкая потребность в витаминах, жирных кислотах и кислороде; относительная устойчивость к низкому рН; способность к флокуляции; синтез «киллер-факторов»; толерантность к высокому осмотическому давлению; синтез органолептически значимых компонентов (органических кислот, сложных эфиров); отсутствие способности к синтезу уксусной кислоты. Подготовка посевного материала выбранного штамма дрожжей начинается с накопления биомассы из клеток чистой лабораторной культуры. Первоначально чистую культуру инокулируют в небольшой объем сока сахарного тростника с концентрацией сухих веществ 5\%, обогащенного питательными веществами и сте- рилизованного сока. Последовательные пересевы осуществляют, используя $400 \mathrm{~cm}^{3}$ инокулята, вводимых в питательную среду с концентрацией 7\% сухих веществ, пока объем посевной суспензии не достигнет $10 \%$ от объема засеваемого сусла. Эти пересевы необходимо вести с тщательным соблюдением производственной санитарии и гигиены.

Согласно Schawn et al. (Schwan, Mendonça, da Silva, Rodrigues, \& Wheals, 2001), микробиота традиционной ферментации сока сахарного тростника сложна. В сбраживаемой среде могут присутствовать разнообразные роды и виды дрожжей, такие как S. cerevisiae, Kluyveromyces marxianus, Pichia heimii, Pichia subpelliculosa, Debaryomyces hansenii и Hanseniaspora uvarum. Молочнокислые и уксуснокислые бактерии и несколько родов, принадлежащие к семейству Enterobacteriaceae, также присутствуют в сбраживаемых средах. Сообщество молочнокислых бактерий, участвующих в процессе ферментации сусла при производстве кашасы, включающее Lactococcus lactis, Lactobacillus plantarum и Lactobacillus fermentum, часто идентифицируется при микробиологических анализах сбраживаемых сред. Некоторые штаммы Lactococcus lactis часто обнаруживаются при ферментации сока сахарного тростника и других видов сырья в качестве контаминантов, особенно в условиях ремесленного производства (Carvalho, Duarte, Dias, Piccoli, \& Schwan, 2015). Этот сложный микробный консорциум дрожжей и бактерий накапливает метаболиты, формирующие уникальные оттенки вкуса и аромата кустарных сортов кашасы.

Все вещества, образующиеся в процессе ферментации и положительно влияющие на органолептические характеристики готового напитка, необходимо сохранить, поэтому дистилляция значимо влияет на качество. Сброженное сусло перегоняют в перегонных кубах или в колоннах непрерывного действия. Кашаса, полученная дистилляцией в перегонном кубе, имеет лучший химический состав и более высокие концентрации конгенеров, чем произведенная в результате непрерывной перегонки (Alcarde, 2014). Дистилляционные колонны используются, как правило, на средних и крупных предприятиях. Большое количество тарелок обеспечивает лучший контроль содержания конгенеров в дистилляте, а также более высокий выход спирта. Традиционно перегонку проводили в медных кубах, обеспечивающих лучшее качество напитка по сравнению с выполненными из других материалов, например, из нержавеющей стали. Медь обладает способностью в процессе дистилляции катализировать определен- 
ные химические реакции, в которые вовлекаются летучие компоненты «вина» (сброженного сусла). Это способствует устранению неприятных запахов при перегонке (Medeiros et al., 2017). Дистиллят, полученный в кубах из нержавеющей стали, может содержать более высокие концентрации серосодержащих соединений, образовавшихся при ферментации. Однако, медь может «переходить» в дистиллят под действием паров спирта, усиливаемого повышенной кислотностью дистиллята, и таким образом загрязнять конечный продукт. Следовательно, медь всегда присутствует в дистиллятах, полученных в перегонных кубах, на внутренних стенках которых происходит окисление меди. «Вино», содержащее от 7\% до 12\% (об./ об.) этанола, подвергается воздействию температур из диапазона 92,6 - 95,9 $\mathrm{C}$. Разделение на фракции происходит благодаря различиям в температурах кипения вещества. Первая фракция отделяется при температурах ниже точки кипения этанола и содержит метанол, альдегиды (ацетальдегид) и сложные эфиры (метил-, этилацетат). Эта фракция называется «головой», ее объем составляет 1 - 5\% от исходного объема «вина». Целевую фракцию, «сердце», из которой и будет получена кашаса, собирают при промежуточных температурах кипения. Ее объем составляет 80\% от объема сброженного сусла. «Хвост» составляет около 15\% от объема «вина». Головная и хвостовая фракции должны быть удалены, так как они содержат соединения, ухудшающие качество напитка.

С начала 1990-х годов в Бразилии при производстве кашасы и других крепких спиртных напитков из сахарного тростника начали применять бидистилляцию с целью снизить в них содержание этилкарбамата (Medeiros et al., 2017). Процесс бидистилляции применим при использовании медных перегонных кубов и направлен на улучшение и стандартизацию качества напитка. Сначала получают дистиллят «вина», собранный без разделения фракций [sic]. Этот дистиллят называется флегмой (Medeiros et al., 2017) (иными словами он может быть обозначен как «спирт-сырец») и содержит около $21 \%$ этанола. При второй перегонке отделяются три фракции: «голова», «сердце» (65\% этанола) и «хвост».

Хранение или «отдых» кашасы должно происходить в емкости из инертного материала (нержавеющей стали или стекла), который не придает напитку запаха и вкуса и предотвращает инфицирование. Напротив, выдержка (созревание) направлена на улучшение сенсорных характеристик, качества и повышение цены напитка. Выдержка заключается в хранении кашасы в де- ревянных бочках максимальной вместимостью 700 л в течение определенного времени. При этом происходят изменения в химическом составе, аромате, вкусе и цвете напитка (Aquino, Rodrigues, Nascimento, \& Casimiro, 2006). Ряд химических реакций, протекающих при выдержке, зависит от породы используемой древесины, продолжительности стадии и качества исходного дистиллята. Объем бочки также важен, так как влияет на площадь контакта древесины и жидкости. Некоторые реакции основаны на разложении макромолекул древесины (лигнин, целлюлоза и гемицеллюлоза), их продукты обогащают напиток в дополнение к экстрагируемым компонентам древесины (Vivas et al., 2020). Кроме того, многие соединения образуются в результате реакции между соединениями древесины с исходными компонентами дистиллята и между «вторичными» соединениями, образующимися при дистилляции. Законодательство Бразилии (Medeiros et al., 2017) разделяет кашасу на три типа: выдержанная, премиальная и экстра премиальная. Разница между ними связана со сроком хранения и сроком годности. При производстве выдержанной и премиальной кашасы выдержку проводят не менее 1 года. В выдержанную кашасу при купажировании можно добавлять до 50\% невыдержанной. Премиальная кашаса должно быть выдержанной на 100\%. Кашаса типа экстра премиальная имеет минимальный срок выдержки 3 года и не может содержать невыдержанную кашасу.

Хотя самой традиционной древесиной, используемой в Бразилии при выдержке алкогольных напитков, является дуб, для выдержки кашасы часто используют и другие породы, в частности, бальсу и местные бразильские породы (Bortoletto \& Alcarde, 2013). Из древесины разных пород экстрагируются свои особые компоненты. Некоторые породы только увеличивают кислотность кашасы и не влияют на ее цвет или вкус.

Продолжительность выдержки определяет некоторые сенсорные характеристики напитка. Так, по мере ее увеличения происходят снижение $\mathrm{pH}$ и концентраций метанола и этанола при возрастании цветности и концентраций этилацетата, ацетальдегида, ацетона и фенольных соединений. «Молодая» кашаса прозрачна. После нескольких месяцев выдержки напиток приобретает ванильный оттенок. Через 1 - 2 года формируется аромат, характерный для использованной породы дерева. Через 3 года выдержки в деревянной бочке аромат становится гармоничным. После этого уже трудно определить вклад продуктов ферментации и ве- 
ществ, экстрагированных из древесины, так как они оказывают комплексное влияние на органолептику кашасы (Medeiros et al., 2017).

Традиционная технология кашасы продолжает совершенствоваться: так, например, при ведении производственного процесса предложено применение современных мембранных технологий (Karp, Hamerski, Silva, \& Medeiros, 2019).

Производство рома включает те же основные этапы, что и производство многих других крепких спиртных напитков, то есть, сбраживание сусла, дистилляцию и выдержку в контакте с древесиной. Отличают эту технологию параметры/условия проведения отдельных стадий, отмеченные ниже.

Сусло, используемое для сбраживания, может быть приготовлено путем растворения мелассы в воде, представлять свежий сок, извлеченный из сахарного тростника, или их смесь. Сусло в среднем имеет концентрацию сахаров 17 - 24\% и рН 4.8 - 5.0, в него могут добавлять некоторые питательные вещества, например, соли. Сусло могут пастеризовать перед засевом дрожжами инокуляцией для лучшей микробиологической стабильности, ограничивая рост бактерий, которые могут нарушить нормальный ход брожения или вызвать неприятный запах (Harris \& West, 1988; Murtagh, 2003).

Тростниковая меласса в среднем содержит в своем составе 55\% сбраживаемых сахаров, из которых примерно 35\% - сахароза и 20\% - смесь глюкозы и фруктозы. Относительная, по сравнению с соком сахарного тростника, стабильность при хранении и низкая стоимость делают ее отличным сырьем бродильных производств (Murtagh, 2003). Одной из первых стадий процесса рафинирования сахара является прессование сахарного тростника для получения сладкого сока. Сок мутный, желтоватого цвета, имеет очень сладкий вкус, содержит от 10\% до 15\% мас./об. сахаров, имеет низкую микробиологическую стабильность и может быстро ферментироваться бактериями и дрожжами атмосферного воздуха, поэтому сколь-нибудь длительное хранение сока обычно не практикуется (Murtagh, 2003). Характеристики патоки, определяющие вкус рома и его насыщенность, варьируют и зависят от качества тростника, почвы, климатических условий, методов сбора урожая и производства сахара, а также обработки и хранения.

Целью ферментации в производстве рома является глубокое сбраживание сахаров в этанол и конгенеры (органические кислоты, альдегиды, сложные эфиры и спирты), придающие вкус и аромат го- товому напитку. Все соединения должны присутствовать в сбалансированных количествах, чтобы ром имел высокое качество.

При производстве светлого рома сусло сбраживают обычно в течение 20 - 26 часов, при этом спонтанная ферментация может длиться $2-4$ дня или даже 1 - 3 недели при получении более крепкого рома. Оптимальные температуры для большинства штаммов дрожжей находятся в диапазоне $31-32^{\circ} \mathrm{C}$; однако из-за высокой стоимости систем поддержания и контроля температуры брожение ведут при комнатной температуре (Medeiros et al., 2017). Некоторые «тропические» штаммы дрожжей обеспечивают высокий выход спирта при температурах $34-36^{\circ} \mathrm{C}$; есть даже упоминания о штаммы с высокой продуктивностью по спирту при температурах до $40^{\circ} \mathrm{C}$ (Fleet \& Green, 2010).

Сусло в технологии рома сбраживается дрожжами Saccharomyces cerevisiae и Schizosaccharomyces pombe. Штаммы S. cerevisiae при ферментации рома используются как «стартовые» культуры и обеспечивают более быстрое сбраживание с накоплением большего количества высших спиртов и жирных кислот, но меньшего - эфиров, в результате ром имеет более легкий вкус. Schiz. pombe сбраживают сусло медленнее, накапливая меньше высших спиртов и жирных кислот, но больше эфиров, что дает более «тяжелый», ароматный ром. Росту этих дрожжей способствуют более низкие значения рН среды культивирования и более высокие концентрации сахаров в ней (Walker \& Stewart, 2016). В сбраживаемых средах могут также развиваться бактериальные культуры. Взаимосвязь между микробными сообществами, участвующими в ферментации, типом рома и содержанием в нем летучих компонентов представлена в Таблице 5 .

Проведение ферментации периодическим способом позволяет получать ром с разными характеристиками на одном и том же оборудовании.

Сброженное сусло содержит от 5\% до 10\% этилового спирта в зависимости от штамма дрожжей, концентрации сахара в сусле, температуры и продолжительности брожения. По окончании ферментации сброженное сусло обычно оставляют «в покое» на 6 - 12 ч для того, чтобы затем провести декантацию и отделить нерастворенные частицы и мертвые дрожжевые клетки для лучшей дистилляции.

На протяжении долгого времени сбраживание сусла проводили сугубо кустарным способом, в 
Таблица 5

Содержание летучих соединений, ферментация сусла и микробиота при производстве различных типов рома (Medeiros et al., 2017)

\begin{tabular}{|c|c|c|c|c|}
\hline Сырье & «Легкий» ром & «Тяжелый» ром & $\begin{array}{c}\text { «ромышлен- } \\
\text { ный» ром }\end{array}$ & Pom «Agricole» \\
\hline & Меласса & Меласса & Меласса & $\begin{array}{l}\text { Сок сахарно- } \\
\text { го тростника }\end{array}$ \\
\hline Летучие компоненты ${ }^{\mathrm{a}}$ & $>225$ & >800 (эфиры >500) & $>225$ & $>225$ \\
\hline Ферментация & Чистая & Смешанная & Смешанная & Смешанная \\
\hline Микробиота & Saccharomyces & $\begin{array}{l}\text { Бактерии, } \\
\text { Schizosaccharomyces }\end{array}$ & $\begin{array}{l}\text { Бактерии, } \\
\text { Saccharomyces }\end{array}$ & $\begin{array}{l}\text { Бактерии, } \\
\text { Saccharomyces }\end{array}$ \\
\hline
\end{tabular}

Примечание: ${ }^{\text {}}$ г/гектолитр чистого спирта

большинстве случаев, в медных или деревянных емкостях. При этом необходима, по меньшей мере, двойная дистилляция для того, чтобы получить спирт желаемого качества и с крепостью примерно 76\% об./об. (Medeiros et al., 2017).

В современных индустриальных условиях дистилляцию проводят в колоннах непрерывного действия, обеспечивающих лучший контроль процесса и более высокое качество дистиллята, позволяющих достигать крепость 95\% об./об. Именно таким образом получают большую часть всего производимого в мире рома, периодическая дистилляция в перегонных кубах характерна для мелких ремесленных производителей (Harris \& West, 1988).

Дистиллят выдерживают в деревянных бочках, обычно из американского дуба, ранее использовавшихся для производства бурбона или некоторых сортов виски, хотя на некоторых островах, ранее бывших французскими колониями, предпочитают использовать бочки, в которых созревали коньячные спирты (Medeiros et al., 2017). В большинстве случаев бочки обугливают (обжигают) изнутри перед заполнением дистиллятом, для того, чтобы вызвать разложение целлюлозы и лигнина под воздействием тепла. Последующая экстракция продуктов такого разложения приводит к формированию характерных оттенков вкуса готового рома. Кроме того, образование активированного угля приводит к уменьшению концентрации веществ с неприятным запахом (Bortoletto \& Alcarde, 2013). Если выдержка проводится в металлических резервуарах, для формирования необходимого химического состава рома могут использовать обугленные щепки.

Из-за пористой структуры древесины, ею сорбируется множество различных соединений и, кроме того, через стенки бочки происходит испарение части этилового спирта, наряду с некоторыми другими компонентами дистиллята, в процессе выдержки.
При температурах окружающей среды, характерных для тропиков, ром созревает гораздо быстрее, чем виски в Шотландии или Ирландии. Скорость испарения этанола в тропиках может достигать $10-12 \%$ в год, тогда как в холодном климате Шотландии она составляет всего 2-4\% в год. Следует учитывать также вид древесины, из которой изготовлена бочка - от него зависит пористость материала, также влияющая на скорость испарения.

Окислительные реакции, конденсация, этерификация и экстракция ароматических альдегидов, танинов и вещества, родственные лигнину, придают выдержанному рому характерные вкус, аромат и цвет (Bortoletto \& Alcarde, 2013).

Продолжительность выдержки колеблется в широких пределах - достаточно типичной является трехлетняя, однако при производстве некоторых сортов рома она может достигать и 15 лет (Pino, Winterhalter, Gök, \& González, 2017).

Купажирование выдержанных дистиллятов с разными показателями позволяет производителю получать различные сорта рома с определенными органолептическими характеристиками. Например, трехлетний выдержанный «тяжелый» ром могут смешивать с «легким» ромом для получения рома с желаемыми сортовыми показателями. При производстве некоторых сортов рома добавляют сахар, специи и жженый сахар для формирования заданных вкуса, цвета и аромата (Harris \& West, 1988; Murtagh, 2003).

\section{Выводы}

Приведенная выше информация позволяет, по нашему мнению, сделать несколько выводов. Напитки, в том числе, крепкие, произведенные из 
продуктов переработки сахарного тростника, пользуются устойчивым спросом во многих густонаселенных регионах мира. Из них в Российской Федерации наибольшими известностью и спросом пользуется ром. На его потребительские характеристики влияет значительное количество факторов, включая тип и качество исходного сырья, используемое оборудование, материалы, из которых оно изготовлено, ведущие сбраживание сусла микробные культуры, параметры проведения ключевых технологических стадий. Варьирование этих факторов позволяет выпускать сорта рома, имеющие свойственную только им органолептику.

Сахарный тростник не культивируется в Российской Федерации из-за неподходящих для него климатических условий, а импорт тростниковой мелассы, тем более, сока затруднены по организационным и экономическим причинам. Принимая во внимание это обстоятельство, с нашей точки зрения целесообразно проведение исследований возможности производства напитка типа «ром» из нетрадиционного сырья, например, свекловичной мелассы, и установление параметров технологического процесса, обеспечивающих максимальное приближение органолептических характеристик готовой продукции к «классическим», присущим тем или иным типам/сортам рома, изготовленным каноническим способом.

\section{Литература}

Быстров, А. А. (2016). Питейная торговля в дореформенной Москве. В Р. А. Алексеев, С. Ф. Вититнев \& С. Н. Федорченко (Ред.), Наука на благо человечества - 2016. Актуальные проблемы истории, политологии и права: Материалы Всероссийской научно-практической конференции преподавателей, аспирантов и студентов (с. 6-9). М.: ИИУ МГОУ.

Копелев, Д. Н. (2011). Корабельная пища XVI XVIII вв. и гастрономические пристрастия пиратов. Этнографическое обозрение, 1, 48-66.

Чеботарева, С. С. (2015). Исследование рынка крепкой алкогольной продукции на основе крупнейших компаний-производителей и их брендов. В С. К. Волкова \& Л. С. Шаховская (Ред.), Актуальные вопросы экономического развития регионов: Сборник материалов $I V$ Всероссийской заочной научно-практической конференции (с. 57-62). Волгоград: ВолгГТУ.

Alcarde, A. R. (2014). Cachaça: Ciência, Tecnologia e Arte [Cachaca: Science, Technology and Art]. Săo Paulo: Blücher.
Aquino, F. W. B., Rodrigues, S., Nascimento, R. F., \& Casimiro, A. R. S. (2006). Simultaneous determination of aging markers in sugarcane spirits. Food Chemistry, 98(3), 569-574. https:// dx.doi.org/10.1016/j.foodchem.2005.07.034

Arif, S., Batool, A., Nazir, W., Khan, R., \& Khalid, N. (2019). Physiochemical characteristics nutritional properties and health benefits of sugarcane juice. Non-Alcoholic Beverages, 6, 227-257. http://dx.doi. org/10.1016/B978-0-12-815270-6.00008-6

Bamforth, C. W., \& Cook, D. J. (2019). Distilled alcoholic beverages. In Food, fermentation and micro-organisms (pp. 131-142). (3rd ed.). Hoboken, NJ: Wiley Blackwell.

Belmonte-Sánchez, J., Gherghel, S., Arrebola, F. J., Romero-González, R., Vidal, J., Parkin, I., \& Frenich, A. (2018). Rum classification using fingerprinting analysis of volatile fraction by headspace solid phase microextraction coupled to gas chromatography-mass spectrometry. Talanta, 187, 348-356. https://dx.doi.org/10.1016/j.talanta.2018.05.025

Belmonte-Sánchez, J., Romero-González, R., Arrebola, F. J., Vidal, J., \& Frenich, A. (2019). An innovative metabolomic approach for golden rum classification combining ultrahigh-performance liquid chromatography-orbitrap mass spectrometry and chemometric strategies. Journal of Agricultural and Food Chemistry, 67(4), 1302-1311. https://dx.doi.org/10.1021/acs.jafc.8b05622

Bortoletto, A. M., \& Alcarde, A. R. (2013). Congeners in sugar cane spirits aged in casks of different woods. Food Chemistry, 139(1-4), 695-701. https:// dx.doi.org/10.1016/j.foodchem.2012.12.053

Bukovsky-Reyes, S. E. R., Lowe, L. E., Brandon, W. M., \& Owens, J. E. (2018). Measurement of antioxidants in distilled spirits by a silver nanoparticle assay. Journal of the Institute of Brewing, 124(3), 291-299. https://dx.doi. org/10.1002/jib.496

Campos, C. R., Silva, C. F., Dias, D. R., Basso, L. C., Amorim, H., \& Schwan, R. F. (2010). Features of Saccharomyces cerevisiae as a culture starter for the production of the distilled sugar cane beverage, cachaça in Brazil. Journal of Applied Microbiology, 108(6), 1871-1879. https://dx.doi.org/10.1111/ j.1365-2672.2009.04587.x

Capobiango, M., Oliveira, E. S., \& Cardeal, Z. L. (2013). Evaluation of methods used for the analysis of volatile organic compounds of sugarcane (Cachaça) and fruit spirits. Food Analytical Methods, 6, 978-988. http://dx.doi.org/10.1007/s12161-0129550-Z

Carvalho, F., Duarte, W., Dias, D., Piccoli, R., \& Schwan, R. (2015). Interaction of Saccharomyces cerevisiae and Lactococcus lactis in the 
fermentation and quality of artisanal cachaça. Acta Scientiarum Agronomy, 37(1). 51-60. https://dx.doi. org/10.4025/actasciagron.v37i1.18397

Castro, M. C., Bortoletto, A., Silvello, G., \& Alcarde, A. (2020). Lignin-derived phenolic compounds in cachaça aged in new barrels made from two oak species. Heliyon, 6(11), E05586. https://dx.doi. org/10.1016/j.heliyon.2020.e05586

Chinnadurai, C. (2017). Potential Health Benefits of Sugarcane. In C. Mohan (Ed). Sugarcane biotechnology: Challenges and Prospects (pp. 1-12). Springer, Cham. http://dx.doi.org/10.1007/978-3319-58946-6_1

Coelho, C., Brottier, C., Beuchet, F., Elichiry-Ortiz, P., Bach, B., Lafarge, C., \& Tourdot-Maréchal, R. (2020). Effect of ageing on lees and distillation process on fermented sugarcane molasses for the production of rum. Food Chemistry, 303, 125405. https://dx.doi. org/10.1016/j.foodchem.2019.125405

Dal Magro, C., Bulegon, R., \& Gomes, G. (2019). Development of freeze dried sugarcane powder. Revista do Congresso Sul Brasileiro de Engenharia de Alimentos [Journal of the South Brazilian Congress of Food Engineering], 4(1), 23-32. http://dx.doi. org/10.5965/24473650412018023

Davies, R. E. (2018). Sailors and Rum, at Sea and Ashore. In G. Miranker (Ed.). Deadly harpoon: A facsimile of the original manuscript of "The adventure of black peter" by Arthur Conan Doyle with annotations and commentary (pp. 1-12). BSI Press. http://dx.doi.org/10.2139/ssrn.3356173

Fleet, G. H., Green, V. (2010). The microbiology and biotechnology of rum production. In G. M. Walker \& P. H. Hughes (Eds.). Distilled spirits (3, pp. 87-94). (3rd ed.). Nottingham University Press.

Harris, R., \& West, D. H. (1988). Caribbean rum: its manufacture and quality. In M. A. Clarke \& M. A. Godshall (Eds.). Sugar Series (Vol. 3, pp. 313-339). Elsevier. http://dx.doi.org/10.1016/B978-0-44443020-5.50026-6

Karp, J. R., Hamerski, F., Silva, V. R., \& Medeiros, A. (2019). Membrane processing of the Brazilian spirit Cachaça. Journal of the Institute of Brewing, 125(3), 383-388. https://dx.doi.org/10.1002/jib.564

Kumar, A., \& Singh, S. (2020). The benefit of Indian jaggery over sugar on human health. In H.G. Preuss \& D. Bagchi. (Eds.). Dietary Sugar, Salt and Fat in Human Health (pp. 347-359). Academic Press. http:// dx.doi.org/10.1016/B978-0-12-816918-6.00016-0

Maia, A. B., Marinho, L. S., \& Nelson, D. L. (2020). Certification of amburana in the aging of cachaça. Research, Society and Development, 9(12), e3891210644. https://dx.doi.org/10.33448/rsdv9i12.10644

Medeiros, A., Matos, M. E., Monteiro, A., De Carvalho, J. \& Soccol. C. (2017). Cachaça and rum. In
A. Pandey, M. Á. Sanromán, G. Du, C. R. Soccol, \& C.-G. Dussap. (Eds.). Current Developments in Biotechnology and Bioengineering (pp. 451-468). Elsevier. http://dx.doi.org/10.1016/B978-0-44463666-9.00016-9

Meng, Y., Yu, S., Qiu, Z., Zhang, J., Wu, J., Yao, T. \& Qin, J. (2020). Modeling and optimization of sugarcane juice clarification process. Journal of Food Engineering, 291, 110223. http://dx.doi. org/10.1016/j.jfoodeng.2020.110223

Murtagh, J. (2003). Feedstocks, fermentation and distillation for production of heavy and light rums. In The alcohol textbook: A reference for the beverages, fuel and industrial alcohol industries (pp. 243-255). Amsterdam: Elsevier Science B.V.

Nishad, J., Selvan, C. J., Mir, S. A., \& Bosco, S. J. D. (2017). Effect of spray drying on physical properties of sugarcane juice powder (Saccharum officinarum L.). Journal of Food Science and Technology, 54(3), 687-697. http://dx.doi. org/10.1007/s13197-017-2507-X

Oswaldo, S., Gerlange, S., Alvaro, S., Aline, S., Wady, J., \& Leonardo, S. (2019). A Cultura da cana-deaçücar (Saccharum officinarum) e o manejo da irrigaçăo [The culture of sugar cane (Saccharum officinarum) and the management of irrigation]. Revista em Agronegócio e Meio Ambiente [Journal on Agribusiness and Environment], 12(4), 16051625. http://dx.doi.org/10.17765/2176-9168.2019 v12n4p1605-1625

Pino, J. A., Winterhalter, P., Gök, R., \& González, J. C. (2017). Characterisation of aroma-active compounds in commercial aged rums. Acta Alimentaria [Food Act], 46(1), 69-75. https://dx.doi. org/10.1556/066.2017.46.1.9

Pradhan, N., Kumar, D., Singh, P., \& Pisalkar, P. (2020). Sensory and microbial evaluation of microwave treated sugarcane juice. International Journal of Current Microbiology and Applied Sciences, 9(3), 1313-1320. https://dx.doi.org/10.20546/ijcmas. 2020.903.153

Resende Oliveira, É., Caliari, M., Soares Soares Júnior, M., Ribeiro Oliveira, A., Cristina Marques Duarte, R., \& Valério de Barros V. B. E. (2018). Assessment of chemical and sensory quality of sugarcane alcoholic fermented beverage. Journal of Food Science and Technology, 55(1), 72-81. https:// dx.doi.org/10.1007/s13197-017-2792-4

Rivera-Espinoza, Y., Valdez-López, E., \& Hernandez, H. (2005). Characterization of a wine-like beverage obtained from sugarcane juice. World Journal of Microbiology and Biotechnology, 21(4), 447-452. https://dx.doi.org/10.1007/s11274-004-1878-0

Schwan, R. F., Mendonça, A. T., da Silva, J. J., Rodrigues, V., \& Wheals, A. E. (2001). Microbiology and physiology of Cachaça (Aguardente) fermentations. 
Antonie Van Leeuwenhoek, 79(1), 89-96. https:// dx.doi.org/10.1023/A:1010225117654

Do Nascimento de Silva, J. H., Verruma-Bernardi, M. R., \& de Oliveira, A. L. (2020). Cachaça Production in Brazil and its Main Contaminant (Ethyl Carbamate). Scientia Agricola [The farmer science], 77(2), e20180135. https://dx.doi.org/10.1590/1678992x-2018-0135

Sneh, S., Anurag, C., Kuna, A., \& Dhanlakshmi, Kr. (2012). Preservation of sugarcane juice using hurdle technology. Sugar Tech, 14(1), 26-39. http:// dx.doi.org/10.1007/s12355-011-0127-8

Vivas, N., Gaulejac, N., Bourden-Nonier, M.-F., Mouche, C., \& Rossy, C. (2020). Extraction of phenolics from new oak casks during spirit maturation: impact on spirit colour. Journal of the Institute of Brewing, 126(1), 83-89. https://dx.doi.org/10.1002/jib.586

Vivas, N., Picard, M., Bourden-Nonier, M.-F., Vivas de Gaulejac, N., Mouche, C., \& Rossy, C. (2020).
Heartwood dry extract: a key fraction for the quality and the diversity of rums and spirits. Journal of the Institute of Brewing, 127(1), 59-69. https://dx.doi.org/10.1002/jib.631

Walker, G., \& Stewart, G. (2016). Saccharomyces cerevisiae in the production of fermented beverages. Beverages, 2(4), 30. https://dx.doi. org/10.3390/beverages2040030

Wells, E. C., Goudge, C., Tricarico, A. R., Murphy, R., \& Fox, G. L. (2019). Social and environmental impacts of British colonial rum production at betty's hope plantation, Antigua. In Jr. C. Orser (Ed.). Archaeologies of the British in Latin America. Contributions to Global Historical Archaeology (pp. 235-253). Springer, Cham. https://dx.doi. org/10.1007/978-3-319-95426-4_12

Xiao, Z., Liao, X., \& Guo, S. (2017). Analysis of sugarcane juice quality indexes. Journal of Food Quality, 1746982. http://dx.doi.org/10.1155/2017/1746982 


\title{
Beverages Based on Sugar Cane Processing Products
}

\author{
Dmitry V. Karpenko \\ Moscow State University of Food Production \\ 11, Volokolamskoe highway, 125080, Moscow, \\ E-mail:karpenkodv@mgupp.ru \\ Milana M. Dyshekova \\ Moscow State University of Food Production \\ 11, Volokolamskoe highway, 125080, Moscow, \\ E-mail:dyshekovamm@mgupp.ru
}

\begin{abstract}
One of the consequences of globalization as the main trend of recent decades is the growing interest of consumers in a certain region or country in products, in particular, drinks, which were not locally widely popular earlier. The article provides information on non-alcoholic and alcoholic beverages of various strengths, obtained from sugar cane processing products, presents the typical chemical composition of this kind of raw material. The main attention is paid to the classification of cachaça and rum, the technological stages of their production processes, the parameters of these stages and their influence on the consumer characteristics of these drinks. A brief history of cachaça and rum is presented, the information on their share in the segment of spirits on the world market is given. It is noted that the principles of cachaça and rum technologies are similar, but the sequence of the production process stages may differs. The role of secondary yeast metabolites accumulating during the fermentation of wort in the formation of the quality of finished drinks is emphasized. The main groups of these compounds and their representatives, their influence on the organoleptic properties of fermented drinks are given. Information on the genera and types of microorganisms developing in the process of wort fermentation in the production of cachaça and rum is given. Possibility of using various equipment for fermented wort distillation and organization of this process is indicated. In the conclusion, it is noted that in the Russian Federation it is expediently to improve first of all, rum technology, for example, through the processing of non-traditional sugar-containing raw materials.
\end{abstract}

Keywords: sugar cane, sugar cane drinks, cachaça, rum, production technology

\section{References}

Bystrov, A. A. (2016). Piteinaya torgovlya v doreformennoi Moskve [Drink trade in pre-reform Moscow]. In R. A. Alekseev, S. F. Vititnev \& S. N. Fedorchenko (Eds.), Nauka na blago chelovechestva - 2016. Aktual'nye problemy istorii, politologii i prava: Materialy Vserossiiskoi nauchno-prakticheskoi konferentsii prepodavatelei, aspirantov i studentov [Science for the good of humanity - 2016. Actual problems of history, political science and law. Proceedings of the All-Russian scientific-practical conference of teachers, graduate students and students] (pp. 6-9). Moscow: IIU MGOU.

Chebotareva, S. S. (2015). Issledovanie rynka krepkoi alkogol'noi produktsii na osnove krupneishikh kompanii-proizvoditelei i ikh brendov [Research of the market of strong alcoholic products on the basis of the largest manufacturing companies and their brands]. In S. K. Volkova \& L. S. Shakhovskaya (Eds.), Aktual'nye voprosy ekono- micheskogo razvitiya regionov: Sbornik materialov IV Vserossiiskoi zaochnoi nauchno-prakticheskoi konferentsii [Topical issues of economic development of regions: Proceedings of the 4th AllRussian correspondence scientific and practical conference] (pp. 57-62). Volgograd: VolgGTU.

Kopelev, D. N. (2011). Korabel'naya pishcha XVI XVIII vv. i gastronomicheskie pristrastiya piratov [Ship food of the XVI-XVIII centuries and gastronomic preferences of pirates]. Etnograficheskoe obozrenie [Ethnographic review], 1, 48-66.

Alcarde, A. R. (2014). Cachaça: Ciência, Tecnologia e Arte [Cachaca: Science, Technology and Art]. Săo Paulo: Blücher.

Aquino, F. W. B., Rodrigues, S., Nascimento, R. F., \& Casimiro, A. R. S. (2006). Simultaneous determination of aging markers in sugarcane spirits. Food Chemistry, 98(3), 569-574. https://dx.doi. org/10.1016/j.foodchem.2005.07.034

Arif, S., Batool, A., Nazir, W., Khan, R., \& Khalid, N. (2019). Physiochemical characteristics nutritional properties and health benefits of sugarcane juice. 
Non-Alcoholic Beverages, 6, 227-257. http://dx.doi. org/10.1016/B978-0-12-815270-6.00008-6

Bamforth, C. W., \& Cook, D. J. (2019). Distilled alcoholic beverages. In Food, fermentation and micro-organisms (pp. 131-142). (3rd ed.). Hoboken, NJ: Wiley Blackwell.

Belmonte-Sánchez, J., Gherghel, S., Arrebola, F. J., Romero-González, R., Vidal, J., Parkin, I., \& Frenich, A. (2018). Rum classification using fingerprinting analysis of volatile fraction by headspace solid phase microextraction coupled to gas chromatography-mass spectrometry. Talanta, 187, 348-356. https://dx.doi.org/10.1016/j.talanta.2018.05.025

Belmonte-Sánchez, J., Romero-González, R., Arrebola, F. J., Vidal, J., \& Frenich, A. (2019). An innovative metabolomic approach for golden rum classification combining ultrahigh-performance liquid chromatography-orbitrap mass spectrometry and chemometric strategies. Journal of Agricultural and Food Chemistry, 67(4), 1302-1311. https://dx.doi. org/10.1021/acs.jafc.8b05622

Bortoletto, A. M., \& Alcarde, A. R. (2013). Congeners in sugar cane spirits aged in casks of different woods. Food Chemistry, 139(1-4), 695-701. https:// dx.doi.org/10.1016/j.foodchem.2012.12.053

Bukovsky-Reyes, S. E. R., Lowe, L. E., Brandon, W. M., \& Owens, J. E. (2018). Measurement of antioxidants in distilled spirits by a silver nanoparticle assay. Journal of the Institute of Brewing, 124(3), 291-299. https://dx.doi.org/10.1002/jib.496

Campos, C. R., Silva, C. F., Dias, D. R., Basso, L. C., Amorim, H., \& Schwan, R. F. (2010). Features of Saccharomyces cerevisiae as a culture starter for the production of the distilled sugar cane beverage, cachaça in Brazil. Journal of Applied Microbiology, 108(6), 1871-1879. https://dx.doi.org/10.1111/ j.1365-2672.2009.04587.x

Capobiango, M., Oliveira, E. S., \& Cardeal, Z. L. (2013). Evaluation of methods used for the analysis of volatile organic compounds of sugarcane (Cachaça) and fruit spirits. Food Analytical Methods, 6, 978988. http://dx.doi.org/10.1007/s12161-012-9550-z

Carvalho, F., Duarte, W., Dias, D., Piccoli, R., \& Schwan, R. (2015). Interaction of Saccharomyces cerevisiae and Lactococcus lactis in the fermentation and quality of artisanal cachaça. Acta Scientiarum Agronomy, 37(1). 51-60. https://dx.doi. org/10.4025/actasciagron.v37i1.18397

Castro, M. C., Bortoletto, A., Silvello, G., \& Alcarde, A. (2020). Lignin-derived phenolic compounds in cachaça aged in new barrels made from two oak species. Heliyon, 6(11), E05586. https://dx.doi. org/10.1016/j.heliyon.2020.e05586

Chinnadurai, C. (2017). Potential Health Benefits of Sugarcane. In C. Mohan (Ed). Sugarcane bio- technology: Challenges and prospects (pp. 1-12). Springer, Cham. http://dx.doi.org/10.1007/978-3319-58946-6_1

Coelho, C., Brottier, C., Beuchet, F., Elichiry-Ortiz, P., Bach, B., Lafarge, C., \& Tourdot-Maréchal, R. (2020). Effect of ageing on lees and distillation process on fermented sugarcane molasses for the production of rum. Food Chemistry, 303, 125405. https://dx.doi.org/10.1016/j.foodchem.2019.125405

Dal Magro, C., Bulegon, R., \& Gomes, G. (2019). Development of freeze dried sugarcane powder. Revista do Congresso Sul Brasileiro de Engenharia de Alimentos [Journal of the South Brazilian Congress of Food Engineering], 4(1), 23-32. http://dx.doi. org $/ 10.5965 / 24473650412018023$

Davies, R. E. (2018). Sailors and Rum, at Sea and Ashore. In G. Miranker (Ed.). Deadly harpoon: A facsimile of the original manuscript of "The adventure of black peter" by Arthur Conan Doyle with annotations and commentary (pp. 1-12). BSI Press. http://dx.doi.org/10.2139/ssrn.3356173

Fleet, G. H., Green, V. (2010). The microbiology and biotechnology of rum production. In G. M. Walker \& P. H. Hughes (Eds.). Distilled spirits (3, pp. 87-94). (3rd ed.). Nottingham University Press.

Harris, R., \& West, D. H. (1988). Caribbean rum: its manufacture and quality. In M. A. Clarke \& M. A. Godshall (Eds.). Sugar Series (Vol. 3, pp. 313-339). Elsevier. http://dx.doi.org/10.1016/B978-0-44443020-5.50026-6

Karp, J. R., Hamerski, F., Silva, V. R., \& Medeiros, A. (2019). Membrane processing of the Brazilian spirit Cachaça. Journal of the Institute of Brewing, 125(3), 383-388. https://dx.doi.org/10.1002/jib.564

Kumar, A., \& Singh, S. (2020). The benefit of Indian jaggery over sugar on human health. In H.G. Preuss \& D. Bagchi. (Eds.). Dietary sugar, salt and fat in human health (pp. 347-359). Academic Press. http://dx.doi.org/10.1016/B978-0-12-8169186.00016-0

Maia, A. B., Marinho, L. S., \& Nelson, D. L. (2020). Certification of amburana in the aging of cachaça. Research, Society and Development, 9(12), e3891210644. https://dx.doi.org/10.33448/rsdv9i12.10644

Medeiros, A., Matos, M. E., Monteiro, A., De Carvalho, J. \& Soccol. C. (2017). Cachaça and rum. In A. Pandey, M. Á. Sanromán, G. Du, C. R. Soccol, \& C.-G. Dussap. (Eds.). Current developments in biotechnology and bioengineering (pp. 451-468). Elsevier. http://dx.doi.org/10.1016/B978-0-44463666-9.00016-9

Meng, Y., Yu, S., Qiu, Z., Zhang, J., Wu, J., Yao, T. \& Qin, J. (2020). Modeling and optimization of sugarcane juice clarification process. Journal of Food 
Engineering, 291. PMID: 110223. http://dx.doi. org/10.1016/j.jfoodeng.2020.110223

Murtagh, J. (2003). Feedstocks, fermentation and distillation for production of heavy and light rums. In The alcohol textbook: A reference for the beverages, fuel and industrial alcohol industries (pp. 243-255). Amsterdam: Elsevier Science B.V.

Nishad, J., Selvan, C. J., Mir, S. A., \& Bosco, S. J. D. (2017). Effect of spray drying on physical properties of sugarcane juice powder (Saccharum officinarum L.). Journal of Food Science and Technology, 54(3), 687-697. http://dx.doi.org/10.1007/s13197017-2507-x

Oswaldo, S., Gerlange, S., Alvaro, S., Aline, S., Wady, J., \& Leonardo, S. (2019). A Cultura da cana-de-açücar (Saccharum officinarum) e o manejo da irrigaçăo [The culture of sugar cane (Saccharum officinarum) and the management of irrigation]. Revista em Agronegócio e Meio Ambiente [Journal on Agribusiness and Environment], 12(4), 1605-1625. http://dx.doi.org/10.17765/21769168.2019v12n4p1605-1625

Pino, J. A., Winterhalter, P., Gök, R., \& González, J. C. (2017). Characterisation of aroma-active compounds in commercial aged rums. Acta Alimentaria [Food Act], 46(1), 69-75. https://dx.doi. org/10.1556/066.2017.46.1.9

Pradhan, N., Kumar, D., Singh, P., \& Pisalkar, P. (2020). Sensory and microbial evaluation of microwave treated sugarcane juice. International Journal of Current Microbiology and Applied Sciences, 9(3), 1313-1320. https://dx.doi. org/10.20546/ijcmas.2020.903.153

Resende Oliveira, É., Caliari, M., Soares Soares Júnior, M., Ribeiro Oliveira, A., Cristina Marques Duarte, R., \& Valério de Barros V. B. E. (2018). Assessment of chemical and sensory quality of sugarcane alcoholic fermented beverage. Journal of food science and technology, 55(1), 72-81. https://dx.doi. org/10.1007/s13197-017-2792-4

Rivera-Espinoza, Y., Valdez-López, E., \& Hernandez, H. (2005). Characterization of a wine-like beverage obtained from sugarcane juice. World Journal of Microbiology and Biotechnology, 21(4), 447-452. https://dx.doi.org/10.1007/s11274-004-1878-0

Schwan, R. F., Mendonça, A. T., da Silva, J. J., Rodrigues, V., \& Wheals, A. E. (2001). Microbiology and physiology of Cachaça (Aguardente) fermentations. Antonie Van Leeuwenhoek, 79(1), 89-96. https://dx.doi.org/10.1023/A:1010225117654

Do Nascimento de Silva, J. H., Verruma-Bernardi, M. R., \& de Oliveira, A. L. (2020). Cachaça Production in Brazil and its Main Contaminant (Ethyl Carbamate). Scientia Agricola [The farmer science], 77(2), e20180135. https://dx.doi.org/10.1590/1678992x-2018-0135

Sneh, S., Anurag, C., Kuna, A., \& Dhanlakshmi, Kr. (2012). Preservation of sugarcane juice using hurdle technology. Sugar Tech, 14(1), 26-39. http://dx. doi.org/10.1007/s12355-011-0127-8

Vivas, N., Gaulejac, N., Bourden-Nonier, M.-F., Mouche, C., \& Rossy, C. (2020). Extraction of phenolics from new oak casks during spirit maturation: impact on spirit colour. Journal of the Institute of Brewing, 126(1), 83-89. https://dx.doi.org/10.1002/jib.586

Vivas, N., Picard, M., Bourden-Nonier, M.-F., Vivas de Gaulejac, N., Mouche, C., \& Rossy, C. (2020). Heartwood dry extract: a key fraction for the quality and the diversity of rums and spirits. Journal of the Institute of Brewing, 127(1), 59-69. https://dx. doi.org/10.1002/jib.631

Walker, G., \& Stewart, G. (2016). Saccharomyces cerevisiae in the production of fermented beverages. Beverages, 2(4), 30. https://dx.doi.org/10.3390/beverages 2040030

Wells, E. C., Goudge, C., Tricarico, A. R., Murphy, R., \& Fox, G. L. (2019). Social and environmental impacts of british colonial rum production at betty's hope plantation, Antigua. In Jr. C. Orser (Ed.). Archaeologies of the British in Latin America. Contributions to Global Historical Archaeology (pp. 235-253). Springer, Cham. https://dx.doi. org/10.1007/978-3-319-95426-4_12

Xiao, Z., Liao, X., \& Guo, S. (2017). Analysis of sugarcane juice quality indexes. Journal of Food Quality, 1746982. http://dx.doi.org/10.1155/2017/1746982 